\title{
保険薬局による電話連絡とトレーシングレポートを利用した 経口抗がん剂服用外来患者に対する情報提供方法の確立
}

\author{
吉留実慧子 ${ }^{* 1}$, 三宅麻文 ${ }^{2}$, 松山怜奈 ${ }^{1}$, 楠本知代 ${ }^{1}$, 岩井惇子 ${ }^{1}$, 西山啓介 ${ }^{2}$, 小林和博 ${ }^{2}$ \\ 伊藤俊和 ${ }^{2}$, 近藤 篤 $^{2}$, 上田 覚 $^{2}$, 石川弘子 ${ }^{2}$, 河原宏之 ${ }^{2}$, 尾上雅英 ${ }^{2}$ \\ 祥漢堂梅田北薬局 ${ }^{1}$, 公益財団法人田附興風会医学研究所北野病院 薬剂部 ${ }^{2}$
}

\section{Establishment of Information Sharing among Oral Outpatient Chemotherapy Patients, Using Telephone Communication and Tracing-report by Community Pharmacists}

\author{
Mieko Yoshidome*1, Mafumi Miyake², Rena Matsuyama', Tomoyo Kusumoto ${ }^{1}$, Atsuko Iwai ${ }^{1}$, \\ Keisuke Nishiyama ${ }^{2}$, Kazuhiro Kobayashi², Toshikazu Ito², Atsushi Kondo², Satoru Ueda², \\ Hiroko Ishikawa ${ }^{2}$, Hiroyuki Kawahara ${ }^{2}$ and Masahide Onoue ${ }^{2}$ \\ Shoukando-Umedakita Pharmacy ${ }^{1}$, \\ Pharmacy, Kitano Hospital the TAZUKE KOFUKAI Medical Research Institute ${ }^{2}$ \\ $\left[\begin{array}{l}\text { Received October 14, } 2015 \\ \text { Accepted April 6, } 2016\end{array}\right]$
}

Chemotherapy has shifted from hospital care to ambulatory care. To ensure safe and certain ambulatory chemotherapy, a community pharmacist is expected to feed back information about the medicine-taking situation at home to hospital staff.

In this study, we estimated the establishment of a tracing-report system using telephone communication, with the aim of organizing concerted intervention among physicians, hospital pharmacists and community pharmacists.

Among the outpatients who were treated S-1 from June 1, 2014 to April 30, 2015, 25 patients agreed to receive an inquiry call at home. Medication compliance and the number of unused medicines were monitored by a community pharmacist and this information was reported to a physician via a hospital pharmacist by using 'The Tracing Report.' The names of diseases were confirmed in 24 patients, and the chemotherapy method was confirmed in 23 patients. Physicians accepted recommendations from pharmacists in 30 out of 47 cases.

In conclusion, the results suggest that an inquiry call from a community pharmacist during ambulatory care, verifying their medicine taking situation, contributed to safe chemotherapy.

Key words — S-1, community pharmacist, hospital pharmacist, oral chemotherapy, sharing information

緒言

近年，内服の分子標的薬，支持療法の開発に伴 い, 抗がん剂治療の中心は入院治療から外来治療 へとシフトしてきており，保険調剤薬局において も経口抗がん剤の処方を応需する機会は増加して いる. がん化学療法に関与している病院薬剤師か らは「患者・家族の要望に応じた切れ目のないが ん医療の提供」を目指し, 様々な取り組みの報告 がある. ${ }^{1,2)}$
病院薬剤師が保険薬局薬剂師に対して期待する 経口抗がん剂にかかわる業務としては, 病院薬剤 師は外来患者の経口抗がん剂の服用状況を把握す ることが難しいことから, 保険薬局薬剤師が患者 自宅での服薬状況の把握と副作用モニタリングの 結果を処方元病院へフィードバックすることが挙

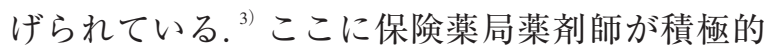
に関与し，病院と情報共有できるようなシステム を構築することで経口抗がん剂の安全な服用につ ながるものと考えられる.

\footnotetext{
*テ530-0016 大阪市北区中崎1-1-1
} 
テガフール・ギメラシル・オテラシルカリウム 配合カプセル（S-1）については, 服用遵守率が 高い患者ほど治療成績がよいという報告があるこ とから, ${ }^{4,5)}$ 当薬局では 2012 年から経口抗がん剤 服用患者のうち， S-1 服用中の患者について，残 薬数の確認を含めた自宅服薬状況, 副作用の発現 の有無を患者とともに把握し, 事前に医師に報告 できるような「S-1 お薬手帳シール」を配布して いた（岩井惇子, P-391, 日本薬郕師会学術大会, 2013 年 9 月，大阪）。しかしながら患者が記録す る「S-1 お薬手帳シール」は有効に活用されずに, シールの内容を診察時に医師へ提示できた患者は 32 例中 1 例のみとほとんどなかった。また，患 者の副作用の発生状況や残薬の発生状況に応じて 処方変更した例は 1 例も認めることができず，患 者情報が十分に伝わっていなかった。

一方，病院から服薬指導依頼書などを薬局側に 提供し，その結果を病院へフィードバックしてい る施設もある ${ }^{1,6)}$ が，大部分の薬局は情報がない 状況で患者指導を実施しているのが現状である. 特に抗がん剂治療を受けている患者については, 病名や併用注射薬などの情報が不明なまま患者指 導を実施している場合がある.そこで今回我々は, 患者面談を通じてがん患者の病名などがどの程度 まで入手することができるか検討した。 また得ら れた患者情報を医師に適切に提供できるシステム の構築を目指して, 保険薬局薬剤師が患者自宅で の服用情報を電話で確認し, 得た情報を病院薬剂 師を介して医師へフィードバックすることによ り，医師が患者診察前の患者情報を確認できるト レーシングレポートシステムを構築しその有用性 について評価した。

\section{方 法}

\section{1. 対象}

2014 年 6 月 1 日〜 2015 年 4 月 30 日の間，当薬 局において S-1（カプセルないしは OD 錠）を調 鼡した患者 48 名とした。

\section{S-1 トレーシングレポートの作成}

患者自宅での服薬状況を報告するためのツール

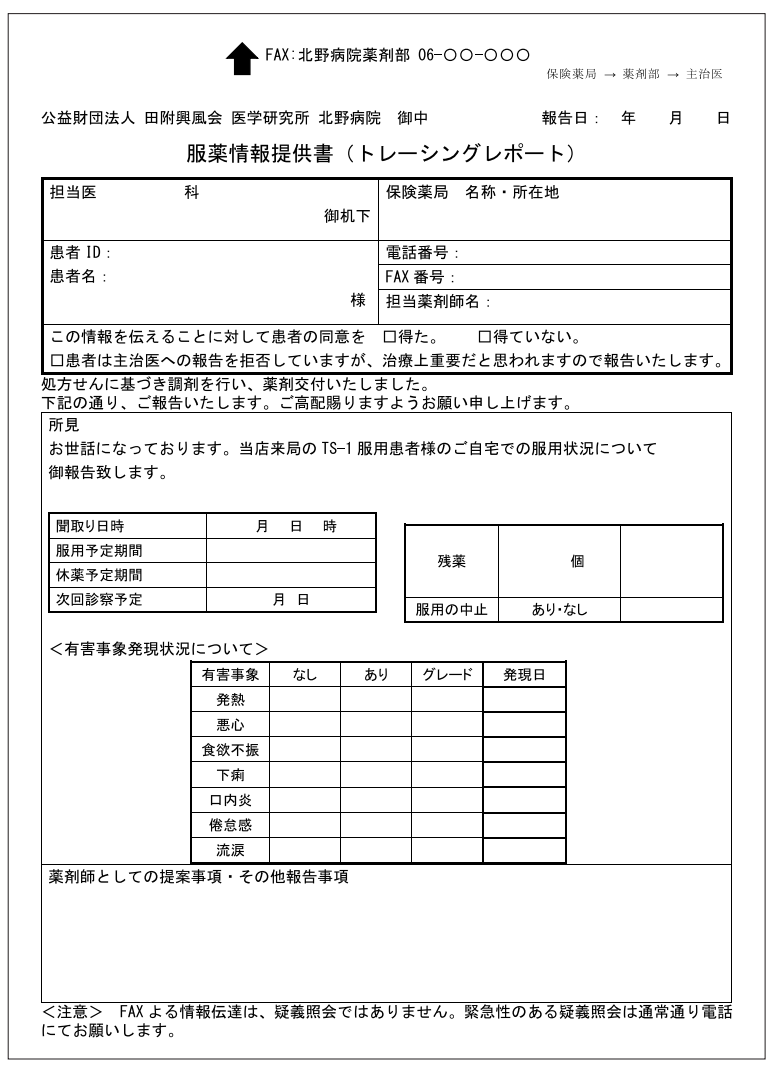

図 1 S-1 トレーシングレポート

は, 京都大学医学部附属病院薬剤部のトレーシン グレポートのフォーマット（http://www.kuhp. kyoto-u.ac.jp/ yakuzai/yakkyoku/20130807_ tracingreport.pdf, 2015 年 9 月 30 日）を参考とした.

電話対応時に確認する 7 項目 (発熱, 悪心, 食 欲不振, 下痢, 口内炎, 倦急感, 流涙) の選定は, 添付文書の「副作用」の項目，メーカーが配布し ている「S-1 の注意すべき自覚的副作用とその対 応」および北野病院薬剤部が初回 S-1 服用患者に 使用している「薬剤説明シート」を参考とした。 そして副作用項目, 服薬期間, 休薬期間, 次回診 察予定日，服用の中止および残薬数を記載できる ような S-1トレーシングレポート（図1）を作成した.

\section{3. 薬局からの患者自宅への電話連絡による承諾 について}

薬剂師 3 名が服薬指導を担当することとし，患 者来院時に患者本人に本取り組みに対する説明文 書を読んでいただき同意を得た。ささらに，患者本 人もしくは家族から「病名」抢よび「現在の治療 方法」を来局時の聞き取りにより確認した。 


\section{4. 自宅療養中患者への電話による確認}

処方せんを応需する毎に薬局から患者自宅への 電話連絡の必要の有無を確認した。電話連絡は, 原則 1 コースの服用期間が終了する日の前後 \pm 2 日間に 1 回行うとし, 事前に連絡希望時間を患者 に確認した。

服薬遵守の確認は服薬期間を守って服用できた かを確認し, さらに現在の薬の残数を報告しても らうこととした。

服用率は過去の報告例 ${ }^{7}$ を参考にして以下のよ うに定義した。

服用率 $=($ 交付時の薬剂数 - 電話連絡時の残数 $)$ / 交付時の薬剂数 $\times 100$

コース終了予定日より前に連絡した場合は，確 認した残数から残りの服用予定量を引いた数を残 薬数とした.

副作用の発生状況については電話連絡時に，上 記 7 項目については, CTCAE v4.0 -JCOG で評価 し，副作用の発現日，患者が気になっていること もしくは診察前に医師に伝えたいことについて調 査した。

\section{5. 病院への報告}

保険薬局は電話連絡当日または翌日にトレーシ ングレポートを病院までファックス送信した。病 院薬剤師はトレーシングレポートの内容を確認 後, 電子カルテに添付し, 担当医には院内メール にて次回患者受診前に医師が閲覧できるように し，その緊急性に応じて医師に直接相談すること とした。

\section{6. トレーシングレポートの効果}

トレーシングレポートの運用がほぼ確立した 7 力月後の 2015 年 1 11 月の期間, 北野病院に届 いたトレーシングレポート 63 件の活用状況につ いて調査した。なお，残薬や副作用の発現なしの みの報告で介入の必要がない 23 件については対 象外としたため，対象の 40 件についてその活用 状況について調査した。

\section{7. 倫理的配慮}

本研究は「人を対象とする医学系研究に関する
倫理指針」を遵守し, 公益財団法人田附興風会医 学研究所北野病院 医の倫理委員会の承認を得て 実施した（承認番号：E15-11-005）。

\section{結果}

\section{1. 薬局からの患者自宅への電話連絡による承諾 について}

48 名中 26 名（男性 16 名女性 10 名）が自宅へ の電話連絡による服薬状況確認を承諾した. 22 名については電話連絡を断ったが, その理由は「飲 み方はわかっている」6名,「メーカー配布手帳を 使用するので不要」 1 名, 「入院予定あり」3 名, 「耳 が不自由なので不要」 1 名抒よび「回答なし」 11 名であった。なお電話連絡を承諾したが連絡がつ かなかった 1 名は除外したため, 以下 25 名につ いて解析した.

\section{2. 薬局聞き取りによる患者背景の把握}

患者聞き取り調査結果を表 1 に示す。病名に ついては 25 名中 24 名から聞き取ることができた が，1名については未回答であった．24名中 9 名 についてはがん病期までの情報が収集できたが, 残りの 15 名については確認することができな かった.

現在の治療法については，25名中 23 名は確認 でき, S-1 単独治療が 11 名, 注射もしくは放射 線併用療法は 9 名で, S-1 以外の内服薬の併用が 1 名であった. 2 名の患者については治療法まで は確認できなかった。

表 1 把握できた患者背景

\begin{tabular}{lcccc}
\hline \hline \multicolumn{1}{c}{ 病名 } & 患者数 & $\begin{array}{c}\text { Stage } \\
\text { 把握 }\end{array}$ & $\begin{array}{c}\text { 注射薬 } \\
\text { 併用 }\end{array}$ & $\begin{array}{c}\text { 放射線 } \\
\text { 併用 }\end{array}$ \\
\hline 胃がん & 8 & 5 & 3 & \\
膵がん & 4 & & & \\
大腸がん & 4 & & 1 & 1 \\
頭頸部がん & 1 & & & \\
胆管がん & 1 & & & \\
乳がん & 2 & 2 & & \\
肺がん & 4 & 2 & 4 & \\
未回答 & 1 & & & \\
\hline & 25 & 9 & 8 & 1
\end{tabular}




\section{3. 自宅療養中患者への電話連絡希望状況}

患者 25 名の保険薬局からの電話による聞き取 りの希望を調查したところ，処方せん受け取り回 数は合計 133 件であり，そのうち電話連絡を希望 した回数は 77 回 $(57.9 \%)$ であった。患者 1 人 当たりの処方せん受け取り回数の平均は 5.3 回で

表 2 処方箋受け取り回数と電話連絡承諾回数

\begin{tabular}{|c|c|c|}
\hline 患者 & 処方せん回数 & 電話承諾回数 \\
\hline 1 & 1 & 1 \\
\hline 6 & 2 & 1 \\
\hline 2 & 2 & 2 \\
\hline 3 & 2 & 2 \\
\hline 4 & 2 & 2 \\
\hline 5 & 2 & 2 \\
\hline 8 & 3 & 1 \\
\hline 7 & 3 & 3 \\
\hline 10 & 4 & 1 \\
\hline 9 & 4 & 3 \\
\hline 11 & 4 & 3 \\
\hline 12 & 5 & 2 \\
\hline 14 & 5 & 3 \\
\hline 13 & 5 & 4 \\
\hline 16 & 6 & 4 \\
\hline 15 & 6 & 5 \\
\hline 19 & 7 & 2 \\
\hline 18 & 7 & 5 \\
\hline 17 & 7 & 6 \\
\hline 21 & 8 & 4 \\
\hline 20 & 8 & 5 \\
\hline 22 & 9 & 1 \\
\hline 24 & 10 & 2 \\
\hline 23 & 10 & 7 \\
\hline 25 & 11 & 6 \\
\hline 合計 & 133 & 77 \\
\hline 平均 & 5.3 & 3.1 \\
\hline
\end{tabular}

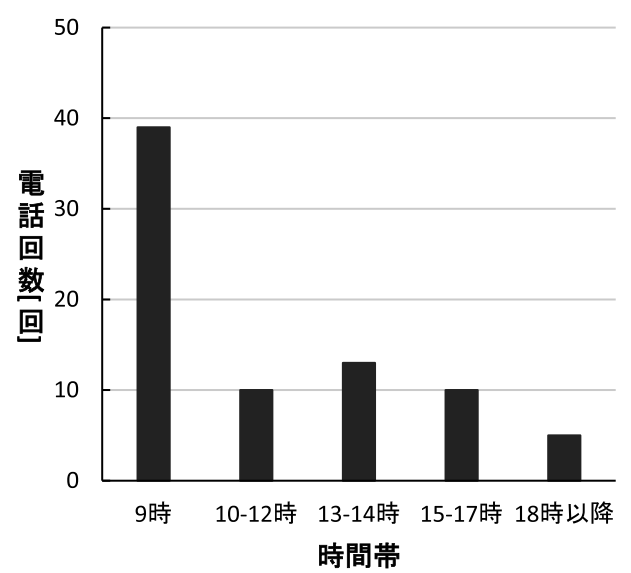

図 2 薬局からの電話連絡時間帯
あり, 平均電話連絡回数は 3.1 回であった（表 2). 電話連絡時間带は 9 時台が 39 回と最も多かった (図 2)

\section{4. 電話による自宅での服薬状況の把握}

77 件の電話連絡時に残薬数を確認したところ, 1 コースの服薬期間中 $100 \%$ 服用していた件数は 63 件であり，それ以外は 14 件であった。 それ以 外の理由について調査したところ, Grade 1 では あるが病院から事前に服用中止基準の指導があっ た発熱，下㾥による服用の中止が 8 件であった. その他の理由としては, 服用忘れが 2 件, 服用数 の誤りは 1 件および不明は 3 件であった。

また同時に副作用の発現状況についても確認し たところ, Grade 2 以上発現した副作用はなかった.

\section{5. トレーシングレポートの効果}

40 件のトレーシングレポートを「副作用発現 状況のみの情報提供」,「副作用発現状況および処 方依頼」と「副作用発現状況扮よび残薬調整依頼」 の3つに分類したところ, トレーシングレポート 1 件につき複数記載している例もあったため, 合 計 47 件となった。その結果を図 3 ，具体例を表 3 に示す.

「副作用発現状況のみの情報提供」については, 34 例中 19 例 (55.9\%) が薬剂の追加, 減量や副 作用評価結果のカルテへの記載など情報提供が反 映されていた．また，処方依頼まであった 4 例に ついては, 口内炎予防薬の処方の追加など 4 例中 全てが処方追加されていた。最後に服用状況を確

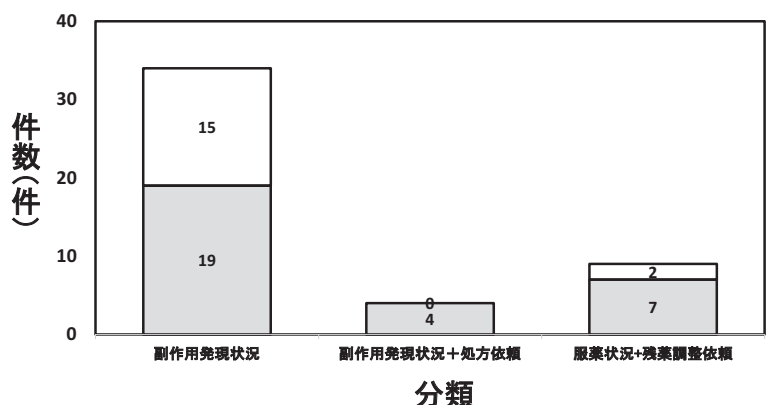

図３トレーシングレポートによる報告内容と処方 への反映

$\square$ 処方への反映なし $\square$ 処方への反映あり 
表 3 トレーシングレポートによる報告内容と治療への影響

\begin{tabular}{|c|c|}
\hline 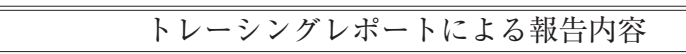 & 治療への影響 \\
\hline 味覚異常や食欲不振の訴え & ポラプレジンクや栄養剤の処方 \\
\hline 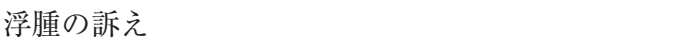 & 利尿剂の処方 ～～～～～～～ \\
\hline 鼻出血の訴え & 耳鼻咽喉科への対診依頼 \\
\hline 下痢が 1 日 5 回以上の訴えに対し止瀉薬の処方依頼 & ロペラミドの処方 \\
\hline 口内炎予防として含嗽剤の処方依頼 & アズレンスルホン酸 $\mathrm{Na}$ の処方 \\
\hline 湿疹に対するステロイドの処方依頼 & アルクロメタゾンプロピオン酸エステル軟膏の処方 \\
\hline 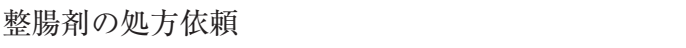 & 酪酸菌製剤の処方 \\
\hline 残薬数の報告 & 処方日数の調整 \\
\hline
\end{tabular}

認後, 残薬の調整依頼を行った 9 例については, 7 例（83.3\%）は残薬状況が反映されたうえで処 方されていた。

\section{考察}

医薬分業の発展に伴い，外来患者は保険薬局で 薬を受け取る機会が増えている。保険薬局の新た な業務の試みとして, 厚生労働省からは残薬確認 や在宅支援など自宅療養中患者へのかかわりにつ いての方向性が示されている．特に抗がん剂につ いては副作用の発現頻度が高く, 保険薬局薬剤師 が経口抗がん剂服用中患者に対して，安全に服用 できるよう寄与することは保険薬局の使命の 1 つ である。その使命を果たすためにも病院と保険薬 局の双方向の連携構築は重要であり，今回我々は 病院への患者の情報提供の向上を目指して S-1 服 用中患者への電話連絡支援の取り組みを行った.

まず始めに患者に薬局からの電話連絡承諾の可 否を調査した。保険薬局からの自宅への電話によ る服薬支援について了承した患者は 48 名中 25 名 であり，52\%の患者で承諾を得た。 そのうち 11 名は経口抗がん剂を初めて服用する患者であっ た. 残りの 14 名については，これまでに抗がん 剤治療は受けているが継続して支援してほしいと のことであった．患者からは自宅への電話連絡は ほかの患者を気にすることなくリラックスして話 すことができるとの声もあった。一方, 電話承諾 がなかった患者 22 名中 18 名については, すでに 何らかの抗がん剂治療を行っており, 自宅療養中 の副作用対策についてもこれまでの経験や知識が あった患者であった。電話連絡を断った患者につ
いては，新たな副作用等が発現する可能性がある ため, 電話支援の承諾率を向上させる努力が必要 である

保険薬局薬剂師が病院薬剤師に期待する業務と して, 告知の状況や病名が報告されている. ${ }^{3)}$ 今 回我々は病院からの情報提供がない状況下で保険 薬局薬剤師側から患者への病状等の聞き取り調査 を試みた。 25 名中 24 名の患者については患者面 談によって病名まで把握することができた。レジ メンについては, 一部の患者については保険薬局 側から代表的なレジメン名を示して確認したが, 23 名について現在の治療方法まで確認すること ができた。一方詳しい病期まで確認できたのは 9 名のみであり，病期の詳細な情報までを入手する ことは困難であった。 保険薬局からの聞き取り調 査により, 病名や現在の治療方法については大部 分の患者から直接情報収集が可能であることが判 明した。しかしながら, 告知されていないケース, 病期によって経口抗がん剂の投与スケジュールが 異なる場合，また患者の状態に応じて服用期間が 変更されている可能性もある。適切な患者指導を 実施するためには患者の病状や投与レジメンの情 報を把握することが重要なため, 処方せん上にレ ジメン名を表記 ${ }^{6)}$ あいはFAXを用いた抗がん 剂レジメンの共有化の体制 ${ }^{8)}$ を整備することが重 要かもしれない.

薬局からの電話連絡について患者 25 名の期間 中の処方せんの平均受取り回数は 5.3 回でありそ のうち 3.1 回についてはトレーシングレポートに より自宅服薬状況を事前報告した。電話連絡を中 止した理由について服薬指導記録から調査したと ころ，S-1 予定服用期間完了のためが 2 名, S-1 
中止によるものが 10 名，来局の中断によるもの が 5 名であったＳ-1 中止となった患者の支援方 法についても検討していく必要が考えられた.

電話連絡の希望時間帯についても調査したが, 朝の 9 10 時が 39 回と最も多かった. 何故この 時間帯に集中したのか詳細に調査することはでき なかったが，保険薬局にとっては朝の 9 時台は外 来患者が集中する繁忙時間を避けることができ， 業務時間を有効利用して細やかな服薬支援ができ る時間帯であった。

次に, 電話による服用遵守率の確認を行った. 77 件中 63 件については 1 コース期間中の服用率

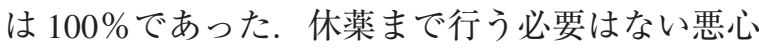
や倦㤐感などの軽微な副作用は発現していたが, 薬局来局時の面談に加えて, 自宅への電話連絡を 行うことで経口抗がん剤の服用量, 休薬期間, 注 意すべき症状，支持療法の適切な使用に対する患 者の理解度を確かめられた。一方，服用率が $100 \%$ ではなかった 14 件のうち，3 件については 服用忘れや服用数の誤りが原因であったため, 電 話連絡のタイミングの見直しを含む患者の指導体 制を強化する必要があると考えられた。残りの 8 件については, Grade 1 程度の副作用 (下痢, 発熱) が発現したが事前に病院から休薬指示があり，患 者が自己判断によって一時的に服用を中止したも のであった。病院と薬局からの指導で患者が無理 な継続をせず安全な服用となったものと考えられ た．患者の自宅状況に応じて病院に連絡する時期 や休薬基準等の指導体制について今後も病院との 連携が必要である.

他施設での取り組みがなされているトレーシン グレポートを参考 ${ }^{9} に$ に，トレーシングレポートの 次回診察時の処方への反映状況について病院側で も調查したところ，47 例中 30 例が処方へ反映さ れていた，特に，具体的な処方依頼まで行った 4 例については受け入れ率は 100\%であった。これ までシールの配布のみで運用していた場合, 診察 時に医師に提示していた患者は 32 例中 1 例のみ でほとんど機能しておらず，患者が提示できない 理由は「医師が忙しそうであったから」等であっ た．今回のトレーシングレポート結果は病院薬剤 師を介して電子カルテへ直接貼付し，さらに医師
に対して事前にメールにて情報を提供するシステ ムを構築したが，本システムにより患者情報をよ り確実に報告できたと考えられる。また，今回は 結果には示していないが医師から㧍礼の連絡が 入った例もあった。しかしながら, 病院薬剤師も 情報提供したトレーシングレポートがその後どの ように反映されたか否かは外来受診時に毎回確認 できない状況である，今後トレーシングレポート による報告を外来受診時に医師がどのように受け 入れ，処方にまで反映されたかを保険薬局薬剤師 に随時伝える手段を確立することが課題である。

以上, 保険薬局薬片師が患者自宅へ電話連絡し て服用状況を確認し，トレーシングレポートを利 用して病院薬剂師と医師へフィードバックする本 システムは患者が安全に経口抗がん剂を服用する ための 1 つの有効な方法であることが示唆された.

\section{利益相反}

開示すべき利益相反はない，我々は保険医療機 関および保健医療養担当規則に従い, 特定の保険 薬局への誘導を行っていない.

\section{引用文献}

1）松田美樹子, 遠藤尚美, 大滝善樹, 後藤恵子, 齋藤 智美, 緒方 操, 鈴木 薰, 高梨伸司, 武田直子, 川越由美, がん化学療法に扔ける薬薬連携一化 学療法情報フィードバックシステムの構築と評 価一, 医薬品相互作用研究, 2014, 38, 90-98.

2) 浅子恵利, 抒薬手帳 (薬薬連携) で行う患者指導, 月刊薬事, 2009, 51, 67-72.

3）後藤愛実, 平 祥子, 細見 誠, 牧智恵子, 西原 雅美, 勝間田敬弘, お薬手帳を利用した薬・薬連 携の意義と課題の検討 - 高柣市の薬剤師による がん化学療法情報の共有状況に関するアンケー 卜より一, 日本病院薬剤師会雑誌, 2013, 49, 641647.

4) Sakuramoto $S$, Sasako M, Yamaguchi $T$, Kinoshita $T$, Fujii M, Nashimoto A, Furukawa H, Nakajima T, Ohashi Y, Imamura H, Higashino M, Yamamura Y, Kurita A, Arai K, Adjuvant Chemotherapy for Gastric Cancer with S-1, an Oral Fluoropyrimidine, $N$ Engl J Med, 2007, 357, 1810-1820. 
5）川端良平, 今村博司, 岸本朋乃, 阿南節子, 安井 友佳子, 藤野美佐子, 藤井千賀, 住田る み, 古河 洋, 胃癌術後S-1補助化学療法における治療継続 性に関する検討, 癌と化学療法, 2011, 38, 793-795.

6) 河添 仁, 上野昌紀, 済川聡美, 田中 守, 田中 亮裕, 荒木博陽, S-1における院外処方せんを利 用した双方向性の情報共有の取り組みとその評 価, 医療薬学, 2014, 40, 441-448.

7）丸山昌広, 久米康予, 田中弘美, 内田仁美, 櫻井 多栄子, 柴崎 泰, 金子 猛, 横井佳博, 綿引洋一, 外来患者における内服抗がん剂の服用状況につ いて, 癌と化学療法, 2012, 39, 485-488.

8）上田浩貴, 倉橋基尚, 中尾祐子, 西田修司, 塚本
泰彦, 井上直也, 濱口良彦, 薬・薬連携を用いた 内服抗がん剤のレジメン共有化, 日本病院薬剤 師会雑誌, 2012, 48, 356-359.

9) 大滝康一, 梅津典子, 麻下智加, 七田知美, 都築 仁美, 石川祥子, 安達知輝, 井上正朝, 小野尚志, 山田武宏, 粟屋敏雄, 小川 聡, 里見真知子, 野田 敏宏, 田崎嘉一, 板垣祐一, 八木真砂子, 田尾 好正, 笠原直邦, 藤沢芳則, 松野和彦, 松原和夫, 薬薬連携: 病院薬剤師が介在する保険調剤薬局 からのトレーシングレポートシステムによる薬 物療法の有効性・安全性への寄与, 医薬ジャー ナル, 2008, 44, 954-960. 